\title{
Rectal Leiomyosarcoma
}

National Cancer Institute

\section{Source}

National Cancer Institute. Rectal Leiomyosarcoma. NCI Thesaurus. Code C5549.

An aggressive malignant smooth muscle neoplasm that arises from the rectum. It is characterized by a proliferation of neoplastic spindle cells. 